\title{
Hubungan Kadar Hemoglobin Ibu Hamil Trimester 3 dengan Antropometri dan Skor APGAR di RSUP. DR. M. Djamil Padang
}

\author{
Muhammad Alhardi Nurdin'1, Yusrawati², Elmatris ${ }^{3}$ \\ ${ }^{1}$ Profesi Dokter Fakultas Kedokteran Universitas Andalas, Padang \\ ${ }^{2}$ Bagian Obstetri dan Ginekologi Fakultas Kedokteran Universitas Andalas, Padang \\ ${ }^{3}$ Bagian Kimia Fakultas Kedokteran Universitas Andalas, Padang
}

\section{A B S T R A C T}

\begin{abstract}
Latar Belakang. Hemoglobin merupakan salah satu bagian darah yang paling penting pada saat ibu hamil karena hemoglobin berperan sebagai pengantar oksigen dan nutrisi dari darah keseluruh tubuh, termasuk janin yang dikandung ibu. Apabila kadar hemoglobin diluar batas normal, bayi yang dilahirkan akan memiliki gambaran antropometri dan skor APGAR yang tidak normal.
\end{abstract}

Objektif. Mengetahui apakah ada hubungan antara hemoglobin ibu hamil dengan antropometri dan skor APGAR bayi baru lahir.

Metode. Analitik retrospektif dan di dukung dengan analisis statistik menggunakan uji korelasi Pearson untuk mendapatkan hubungan variabel independen dengan varibel dependen.

Hasil. Didapatkan hubungan yang bermakna dengan korelasi lemah untuk hubungan hemoglobin ibu hamil dengan berat badan bayi, hubungan yang bermakna dengan korelasi lemah untuk hubungan hemoglobin ibu hamil dengan panjang badan, hubungan yang bermakna dengan korelasi lemah untuk hubungn ibu hamil dengan lingkar kepala bayi, hubungan yang bermakna dengan korelasi lemah untuk hubungan hemoglobin ibu hamil denga skor APGAR 5', dan hubungan yang bermakna dengan korelasi lemah untuk hubungan hemoglobin ibu hamil denga skor APGAR 10'.

Kesimpulan. Adanya hubungan yang bermakna antara hemoglobin ibu hamil trimester ketiga dengan antropometri dan skor APGAR bayi baru lahir.

Kata kunci: antropometri, hemoglobin, skor APGAR.

Background. Hemoglobin is one of the most important parts of blood in pregnant women because hemoglobin supplies oxygen and nutrients throughout the body, including the fetus a mother is carrying. If the hemoglobin level is outside of the normal range, newborn babies will have abnormal anthropometric features and APGAR scores.

Objective. To determine whether there is a relationship between hemoglobin in pregnant women with anthropometry and APGAR score of newborns.

Methods. This study uses a retrospective analytics method and is supported by statistical analysis using the Pearson correlation test to obtain the relationship of independent variables with dependent variables.

Results. A significant relationship with a weak correlation for the relationship of hemoglobin of pregnant women with infant weight, a significant relationship with a weak correlation for the relationship of hemoglobin of pregnant women with body length, a significant relationship with a weak correlation for the relationship of pregnant women with the circumference of a baby's head, a significant association with a weak correlation for the relationship of hemoglobin in pregnant women with an APGAR score of 5', and a meaningful relationship with a weak correlation for an association of hemoglobin in a pregnant woman with an APGAR score of 10'. Conclusion. A significant relationship between hemoglobin in third trimester pregnant women with anthropometry and APGAR score of newborns.

Keywords: anthropometry, APGAR score, hemoglobin

\section{Apa yang sudah diketahui tentang topik ini?}

Hemoglobin merupakan suatu bagian dari darah yang berfungsi sebagai pengikat oksigen dan mengantarkan oksigen ke seluruh jaringan pada tubuh manusia.

\section{Apa yang ditambahkan pada studi ini?}

Hubungan hemoglobin ibu hamil trimester 3 dengan status gizi bayi baru lahir.

\section{CORRESPONDING AUTHOR}

Phone: +628116615195

E-mail: ardinurdin88@gmail.com 
ARTICLE INFORMATION

Received: August $18^{\text {th }}, 2020$

Pendahuluan

Ibu hamil dengan kadar hemoglobin $(\mathrm{Hb})$ rendah merupakan permasalahan yang berbahaya selama kehamilan. Centers For Disease Prevention (CDP) mendefinisikan anemia sebagai kadar hemoglobin yang lebih rendah dari $11 \mathrm{gr} / \mathrm{dl}$ pada trimester pertama dan ketiga dan kurang dari $10.5 \mathrm{gr} / \mathrm{dl}$ pada trimester kedua. ${ }^{1}$ Risiko perdarahan sebelum dan saat persalinan, anemia pada ibu hamil dapat meningkatkan resiko mendapatkan bayi berat lahir rendah (BBLR), bahkan dapat menyebabkan kematian ibu dan bayinya jika ibu hamil tersebut menderita anemia berat. Hal ini memberikan sumbangan besar terhadap angka kematian ibu maupun angka kematian bayi dimana pada tahun 2015 angka tersebut masih cukup tinggi yakni Angka Kematian Ibu (AKI) sebanyak 305 per 100.000 kelahiran hidup dan Angka Kematian Bayi (AKB) sebanyak 26 per 1000 kelahiran hidup. ${ }^{2}$ Gangguan kesehatan yang terjadi selama kehamilan dapat mempengaruhi kesehatan janin dalam kandungan hingga kelahiran dan pertumbuhan bayi selanjutnya. ${ }^{3}$

Rendahnya kadar hemoglobin seringkali dikaitkan dengan status gizi ibu hamil. Pada kehamilan normal terjadi penurunan sedikit konsentrasi hemoglobin dikarenakan hipervolemia yang terjadi sebagai suatu adaptasi fisiologis dalam ke-hamilan. ${ }^{4}$ Konsentrasi hemoglobin <11 gr/dl merupakan keadaan abnormal yang tidak berhubungan dengan hipervolemia tersebut. Ketidakadekuatan hipervolemia yang terjadi dapat mengakibatkan tingginya kadar hemoglobin ibu hamil. ${ }^{5}$ Dengan rendahnya hemoglobin ibu saat hamil, maka ibu akan mengalami terjadinya anemia Pada saat hamil. Ibu akan mengalami masalah kesehatan yang berhubungan dengan rendahnya hemoglobin seperti anemia dan beberapa penyakit yang berhubungan dengan anemia. ${ }^{5}$

Anemia dalam kehamilan merupakan masalah yang banyak ditemukan di seluruh dunia. Prevalensi kejadian anemia di dunia mencapai $41,8 \%$ dan di Indonesia sendiri sebesar 37,1\%. ${ }^{6}$ Sedangkan menurut data laporan bulanan kesehatan ibu dan anak dinas kesehatan provinsi Sumatera Barat kejadian anemia pada ibu di
Revised: May $3^{\text {rd }}, 2021$

Available online: May $27^{\text {th }}, 2021$

provinsi Sumatera Barat sebesar 24,73\% dan untuk kota Padang sendiri mencapai 37,8\% pada tahun 2017.7

Anemia secara fungsional adalah ketidakmampuan sel darah merah dalam mengangkut oksigen ke jaringan perifer. Penentuan anemia atau tidak dapat dinilai melalui tiga konsentrasi, yaitu hemoglobin $(\mathrm{Hb})$ dengan satuan gram $\mathrm{Hb}$ per desiliter $(\mathrm{g} / \mathrm{dL}$ ) atau gram $\mathrm{Hb}$ per liter $(\mathrm{g} / \mathrm{L})$, hematokrit $(\mathrm{Ht})$ dengan satuan persen atau desimal, dan konsentrasi sel darah merah dengan satuan sel per mikroliter $\left(10^{6} / \mu \mathrm{L}\right)$ atau sel per liter $\left(10^{12} / \mu \mathrm{L}\right)$.

Anemia pada ibu hamil mempengaruhi keadaan bayi baru lahir. Menurut studi Mousumi \& Ranjan (2013) anemia pada ibu hamil berhubungan dengan luaran bayi yang buruk seperti lahir prematur dan bayi berat badan rendah serta terminasi kehamilan. ${ }^{8}$ Studi yang dilakukan Gaur dkk (2015) menemukan bahwa ibu yang anemia secara signifikan mempengaruhi pengukuran antropometri bayi dibandingkan dengan ibu yang tidak anemia. ${ }^{9}$

Menurut Hynes dkk (2012) pengukuran antropometri bayi baru lahir adalah berat lahir, panjang lahir, lingkar kepala. ${ }^{10}$ Pengukuran antropometri merupakan suatu penilaian objektif terhadap bayi yang baru lahir. Pematur atau Intrauterine Growth Restriction (IUGR) sendiri dapat disebabkan oleh berbagai hal, salah satunya anemia. Komplikasi yang akan muncul pada anak yakni perawakan pendek, keterlambatan kognitif, dan meningkatnya risiko gangguan neurologis. ${ }^{11}$ Selain itu, dalam penelitian yang dilakukan Ahmad dan Kalsoom pada tahun 2015 ditemukan bahwa $32 \%$ ibu anemia melahirkan bayi dengan Skor APGAR (Appearance, Pulse, Grimace, Activity, and Respiration) yang rendah bila dibandingkan dengan ibu yang tidak anemia. ${ }^{12}$

Selain antropometri, hemoglobin juga mempergaruhi skor AGPAR pada saat ibu melahirkan. Skor APGAR akan menggambarkan bagaimana kesehatan bayi yang baru lahir. Skor APGAR adalah suatu metode penilaian yang digunakan untuk mengkaji kesehatan neonatus dalam menit pertama setelah lahir sampai 5 menit setelah lahir, serta dapat diulang pada menit ke 10.12 Skor APGAR menghitung kuantitas dari 
tanda-tanda klinis depresi neonatal, seperti sianosis atau muka pucat, bradikardia, depresi refleks respon terhadap stimulus, hipotonus, dan apnu atau respirasi yang terganggu.

Peneliti mengambil penelitian ini karena sebelumnya sudah dilakukan penelitian yang terkait di daerah yang berbeda. Hasil penelitian sebelumnya yang di lakukuan oleh Ulfa Rosiana Putri mahasiswi di Fakultas Kedokteran Universitas Islam Negeri Syarif Hidatullah Jakarta di RSPAD Gatot Soebroto menyatakan bahwa hasil hubungan hemoglobin ibu terhadapap antropometri memiliki korelasi bermakna dengan nilai value $\mathrm{p}=0,025 .{ }^{13}$ Dan untuk hubungan antara hemoglobin Ibu terhadap skor APGAR, acuan penelitian yang dipedomankan tidak dilakukan oleh penelitian sebelumnya.

Pengambilan data penelitian, peneliti mengambil data penelitian di Rumah Sakit Umum Pemerintah (RUSP) Dr. M. Djamil kota Padang karena rumah sakit ini memiliki layanan kebidanan. dan Rumah Sakit ini dekat dari Fakultas Kedokteran Universitas Andalas sehingga mempermudah peneliti untuk melakaukan pengambil data. Rumah Sakit ini tidak pernah sebelum melakukan penelitian yang serupa dengan peneliti. Maka, peneliti menetapkan RSUP. Dr. M. Djamil sebagai tempat pengambilan data untuk penelitian.

Karena uraian di atas, pengukuran yang terkait dengan antropometri bayi, penulis hanya meneliti berat lahir, panjang lahir, dan lingkar kepala serta skor APGAR dikarenakan keterbatasan data dan keempat pengukuran tersebut adalah pengukuran yang paling banyak dilakukan di Indonesia. Berdasarkan uraian diatas, penulis tertarik untuk mengetahui hubungan kadar hemoglobin ibu hamil terhadap antropometri dan skor APGAR bayi baru lahir di RSUP. Dr. M. Djamil Padang.

\section{Metode}

Penelitian ini menggunakan analitik retrospektif dengan metode cross-sectional dimana data hemoglobin ibu hamil trimester 3, berat badan, Panjang badan, lingkar kepala, dan skor APGAR di ambil dalam satu waktu yang didapatkan dari rekam medik dan dihubungkan antara variabel dependen (hemoglobin) dengan variabel independent (berat badan, panjang badan, lingkar kepala, dan skor APGAR). Sampel penelitian merupakan bagian dari populasi yang memenuhi kriteria inklusi dan eksklusi. Teknik pengambilan sampel dengan cara consecutive sample, yaitu pengambilan data yang memenuhi kriteria inklusi dan eksklusi yang berurutan dalam kurun waktu tertentu sehingga memenuhi jumlah sampel yang dibutuhkan. ${ }^{33}$

Data yang digunakan untuk penelitian ini adalah semua data rekam medik ibu melahirkan di Bagian Kebidanan RSUP Dr. M. Djamil Padang pada periode tahun Januari 2017 sampai Desember 2018. Setelah data didapatkan, data akan di masuakan ke dalam program Statistical Package for the Social Sciences (SPSS) edisi 19. Setelah data sudah dimasukan dan mendapatkan hasil olahan dari SPSS, maka didapatkan hasil olahan apakah mempunyai hubungan yang bermakna atau tidak dari data variabel dependen dengan variabel independen dari penelitian ini.

\section{Hasil}

Data penelitian diambil dari data sekunder pasien yang melahirkan di Bagian Obstetri dan Ginekologi RSUP. Dr. M. Djamil Padang yang tercatat dari bulan Desember 2019. Pasien yang datanya diambil dalam penelitian ini berjumlah 100 orang. Karakteristik dasar pasien dapat dilihat pada tabel 1 berikut.

Tabel 1 Karakteristik pasien ibu hamil

\begin{tabular}{lcc}
\hline Variabel & Frekuensi & $\begin{array}{c}\text { Persentase } \\
\text { (\%) }\end{array}$ \\
\hline 1. Usia & & \\
20 - 25 tahun & 28 & 28.0 \\
$26-30$ tahun & 37 & 37.0 \\
31 - 35 tahun & 23 & 23.0 \\
36-40 tahun & 12 & 12.0 \\
\hline 2. Paritas & & \\
$\quad$ Primipara & 42 & 42.0 \\
$\quad$ Multipara & 58 & 58.0 \\
$\quad$ Nulipara & 0 & 0.0 \\
\hline 3. Jenis persalinan & & \\
SC & 23 & 23.0 \\
$\quad$ Spontan & 77 & 77.0 \\
\hline 4. Jenis kelamin bayi & & \\
Laki Laki & & \\
$\quad$ Perempuan & 35 & 35.0 \\
$\quad$ Jumlah & 65 & 65.0 \\
\hline
\end{tabular}

Dari data tersebut, untuk data usia yang didapatkan terbanyak adalah usia 26-30 tahun sebanyak 37 orang dan paling sedikit adalah usia 36-40 tahun sebanyak 12 orang. Untuk data paritas yang terbanyak adalah multipara sebanyak 58 orang. Data jenis persalinan yang banyak 
didapatkan adalah ibu melahirkan secara spontan sebanyak 77 orang. Dan untuk data jenis kelamin adalah perempuan sebanyak 65 orang

Pada penelitian didapatkan hasil dari data univariat hemoglobin ibu, berat badan, Panjang kepala dan lingkar kepala bayi serta skor APGAR bayi yang dapat dilihat pada tabel berikut:

Tabel 2 Gambaran rerata kadar hemoglobin ibu hamil trimester 3 di RSUP. Dr. M. Djamil Padang

\begin{tabular}{cc}
\hline Variabel & Rerata \pm SD \\
\hline Kadar Hb Umur 20 - 25 tahun & $11,5 \pm 0,4649$ \\
Kadar Hb Umur 26 - 30 tahun & $11.4 \pm 0,3574$ \\
Kadar Hb Umur 31 - 35 tahun & $11.3 \pm 0,3494$ \\
Kadar Hb Umur 36 - 40 tahun & $11.1 \pm 0,0$ \\
\hline
\end{tabular}

Dari tabel 2, di dapatkan rerata tertinggi untuk hemoglobin ibu hamil pada usia 20 - 25 tahun, meskipun di setiap kategori umur tidak berbeda nyata.

Tabel 3 Gambaran rerata antropometri bayi baru lahir di RSUP.-Dr. M. Djamil Padang

\begin{tabular}{cc}
\hline Variabel & Rerata \pm SD \\
\hline Berat badan $(\mathrm{gr})$ & $2922,5 \pm 230.434$ \\
Panjang badan $(\mathrm{cm})$ & $49,6 \pm 1.343$ \\
Lingkar kepala $(\mathrm{cm})$ & $32,9 \pm 1.189$ \\
\hline
\end{tabular}

Dari tabel 3, di dapatkan rerata antropometri bayi baru lahir yang normal.

Tabel 4 Gambaran rerata skor APGAR bayi baru lahir di RSUP. Dr. M. Djamil Padang

\begin{tabular}{cc}
\hline Variabel & Rerata \pm SD \\
\hline Skor APGAR 5' & $7,4 \pm 0.640$ \\
Skor APGAR 10' & $7,7 \pm 0.640$ \\
\hline
\end{tabular}

Dari data tabel 4, didapatkan rerata skor APGAR 5' dan 10' bayi baru lahir normal.

Dari hasil analisis bivariat, maka didapatkan hasil olahan data berikut:

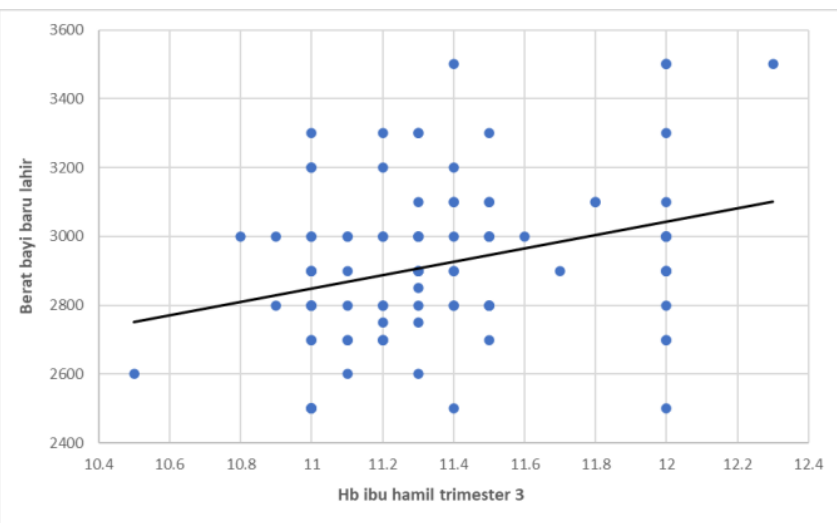

Gambar 1 Grafik Hubungan Hb Ibu Hamil dengan Berat Badan Bayi
Tabel 5 Hubungan kadar hemoglobin ibu hamil dengan berat badan bayi

\begin{tabular}{ccc}
\hline & & Berat badan bayi \\
\hline Hemoglobin ibu hamil & $\mathrm{r}$ & 0,334 \\
& $\mathrm{p}$ & 0,00 \\
& $\mathrm{n}$ & 100 \\
\hline
\end{tabular}

Dari gambar 1 dan tabel 5, didapatkan adanya korelasi lemah yang bermakna antara hemoglobin ibu hamil trimester 3 dengan berat badan bayi baru lahir. Bila di lihat dari gambar 2 , didapatkan adanya garis melintang yang sedikit melandai dan titik persebaran data mendekati garis lurus, sehingga dapat diartikan setiap kenaikan $\mathrm{Hb}$ ibu, maka berat badan bayi baru lahir juga mengalami kenaikan senilai 0,334 dari 1 kenaikan nilai hb ibu hamil.’

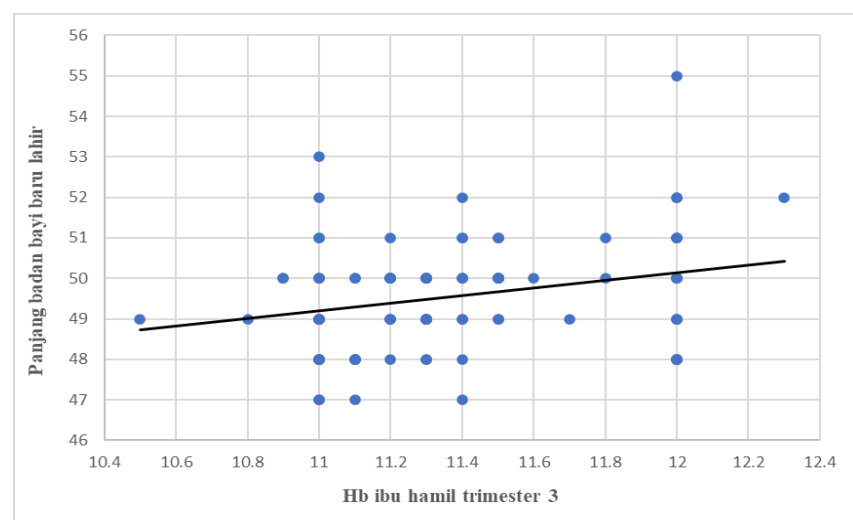

Gambar 2 Grafik Hubungan Hb Ibu hamil dengan Panjang Badan Bayi

Tabel 6 Hubungan kadar hemoglobin ibu hamil dengan panjang badan bayi

\begin{tabular}{ccc}
\hline & \multicolumn{2}{c}{$\begin{array}{c}\text { Panjang badan } \\
\text { bayi }\end{array}$} \\
\hline Hemoglobin ibu hamil & $\mathrm{r}$ & 0,248 \\
& $\mathrm{p}$ & 0,013 \\
& $\mathrm{n}$ & 100 \\
\hline
\end{tabular}

Dari gambar 2 dan tabel 6, terdapat korelasi lemah yang bermakna antara hemoglobin ibu hamil trimester 3 dengan panjang badan bayi baru lahir. Dilihat gambar 2 , dapat diartikan adanya garis melintang yang melandai dan titik persebaran data juga mendekati garis lurus yang diartikan setiap kenaikan hb ibu, maka Panjang badan bayi yang baru juga mengalami kenaikan senilai 0,248 dari 1 kenaikan nilai hb ibu hamil. 


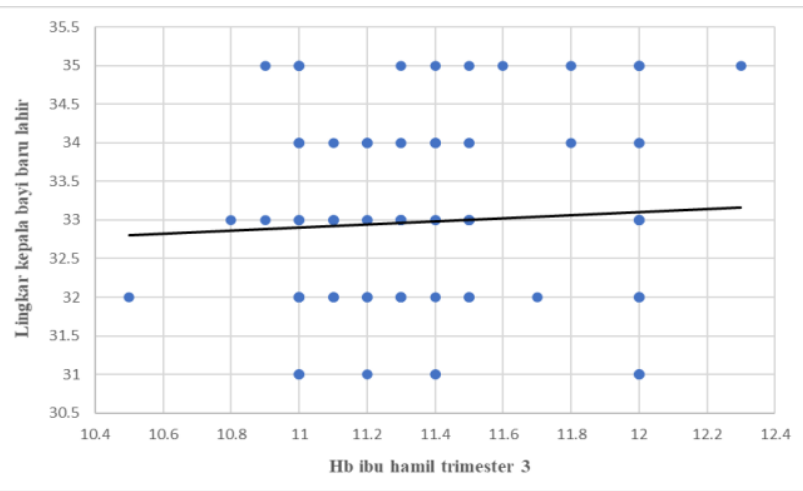

Gambar 3 Grafik Hubungan Hb ibu Hamil dengan Lingkar Kepala Bayi

Tabel 7 Hubungan kadar hemoglobin ibu hamil dengan lingkar kepala bayi

\begin{tabular}{ccc}
\hline & \multicolumn{2}{c}{$\begin{array}{c}\text { Lingkar kepala } \\
\text { bayi }\end{array}$} \\
\hline Hemoglobin ibu hamil & $\mathrm{r}$ & 0,232 \\
& $\mathrm{p}$ & 0,02 \\
& $\mathrm{n}$ & 100 \\
\hline
\end{tabular}

Dari gambar 3 dan tabel 7, terdapat korelasi lemah yang bermakna antara hemoglobin ibu hamil trimester 3 dengan lingkar kepala bayi baru lahir. Dari gambar 4 diatas, dapat diartikan adanya garis melintang yang semakin melandai dan titik persebaran data mendekati garis lurus yang diartikan setiap kenaikan hb ibu, maka lingkar kepala bayi baru lahir juga mengalami kenaikan senilai 0,232 dari 1 kenaikan nilai hb ibu hamil.

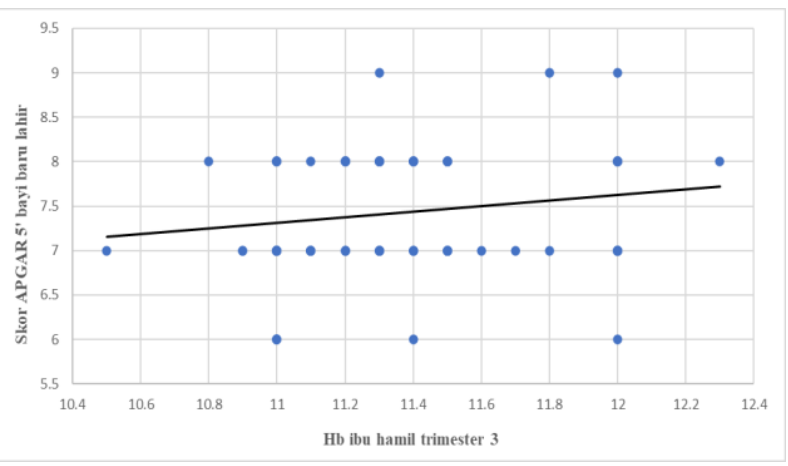

Gambar 4 Grafik Hubungan Hb ibu dengan Skor APGAR 5'

Tabel 8 Hubungan kadar hemoglobin ibu hamil dengan skor APGAR 5' bayi

\begin{tabular}{ccc}
\hline & & $\begin{array}{c}\text { Skor APGAR 5' } \\
\text { bayi }\end{array}$ \\
\hline Hemoglobin ibu hamil & $\mathrm{r}$ & 0,227 \\
& $\mathrm{p}$ & 0,023 \\
& $\mathrm{n}$ & 100 \\
\hline
\end{tabular}

Dari gambar 4 dan tabel 8, didapatnya korelasi lemah yang bermakna antara hemoglobin ibu hamil trimester 3 dengan skor APGAR 5' bayi baru lahir. Dari gambar 5 diatas, dapat diartikan adanya garis melintang yang melandai dan titik persebaran data mendekati garis lurus yang diartikan setiap kenaikan hb ibu, maka skor APGAR 5' bayi baru lahir juga mengalami kenaikan senilai 0,227 dari 1 kenaikan nilai hb ibu hamil.

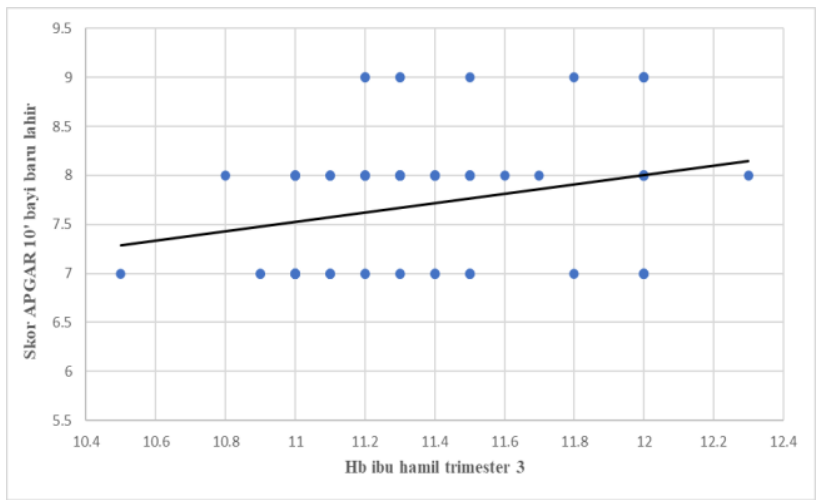

Gambar 5 Grafik Hubungan Hb Ibu Hamil dengan Skor APGAR 10

Tabel 9 Hubungan kadar hemoglobin ibu hamil dengan skor APGAR 10' bayi

\begin{tabular}{ccc}
\hline & & Skor APGAR bayi \\
\hline Hemoglobin Ibu hamil & $\mathrm{r}$ & 0,238 \\
& $\mathrm{p}$ & 0,017 \\
& $\mathrm{n}$ & 100 \\
\hline
\end{tabular}

Dari gambar 5 dan tabel 9, terdapat korelasi lemah yang bermakna antara hemoglobin ibu hamil trimester 3 dengan skor APGAR 10' bayi baru lahir. Pada gambar 6 diatas, dapat diartikan adanya garis melintang yang melandai dan titik persebaran data mendekati garis lurus yang diartikan setiap kenaikan hb ibu, maka skor APGAR 10' bayi baru lahir juga mengalami kenaikan senilai 0,238 dari 1 kenaikan nilai hb ibu hamil.

\section{Pembahasan}

Penelitian ini memiliki variabel independen (hemoglobin ibu hamil trimester 3) dan variabel dependen (antropometri berat badan, panjang badan, lingkar kepala bayi baru lahir dan skor APGAR bayi baru lahir) seperti sudah dijelaskan dalam pendahuluan.

Dari 100 sampel yang diambil, rata-rata hemoglobin ibu hamil trimester 3 adalah 11,4 \pm $0.3234 \mathrm{gr} / \mathrm{dl}$. Data ini sesuai dengan teori Sheerwood yang menjelaskan bahwa rata-rata hemoglobin ibu hamil pada trimester 3 adalah 11 gr/dl. ${ }^{21}$ Karena data ini memiliki standar deviasi yang cukup kecil, maka kita yakin bahwa akurasi 
sampel data cukup tinggi. Untuk antropometri, rata-rata yang didapatkan pada data adalah $2922,5 \pm 230.434$ gr untuk berat badan, 49,5 \pm $1.343 \mathrm{~cm}$ untuk panjang badan dan $32,9 \pm 1.189$ $\mathrm{cm}$ untuk lingkar kepala bayi baru lahir. Nilai rerata yang didapatkan sesuai dengan teori yang sampaikan oleh Greel untuk nilai standar antropometri. ${ }^{25}$ Untuk data terakhir didapatkan rata-rata skor APGAR 5' dan 10' adalah 7,4 \pm 0.640 dan $7,7 \pm 0.640$. Data yang didapatkan sesuai dengan 5 kriteria sederhana dalam teori MacDonald yang meliputi warna kulit, tonus otot, frekuensi jantung, usaha napas dan respon terhadap rangsangan. Setiap penilaian skor APGAR diberi angka 0,1,2. Dari hasil penilaian tersebut dapat diketahui apakah bayi itu normal atau tidak (vigorous baby $=$ nilai APGAR $7-10$ ). ${ }^{29}$

Dari hasil olahan data sampel, didapatkan hubungan yang kuat antara variabel independen dengan semua variabel dependennya, seperti terlihat pada tabel 5.3. Pada tabel 5.3, didapatkan hubungan sangat bermakna antara hemoglobin ibu dengan berat badan bayi baru lahir, yang dibuktikan dengan nilai korelasi $r+0,334$ dan keakuratan nilai $\mathrm{p}=0,00$ (nilai $\mathrm{p}<0,05$ ). Terlihat juga hubungan yang sangat bermakna antara hemoglobin ibu hamil dengan panjang badan bayi baru lahir. Hal ini dibuktikan dengan nilai korelasi $\mathrm{r}+0,248$ dan nilai keakuratan $\mathrm{p}=0,013$ (nilai $\mathrm{p}<$ $0,05)$. Tabel 5.3 juga menunjukkan hubungan sangat bermakna antara hemoglobin ibu dengan lingkar kepala bayi baru lahir, dengan nilai korelasi $r+0,232$ dan keakuratan nilai $p=0,02$ (nilai $\mathrm{p}<0,05$ ). Dan untuk hubungan antara hemoglobin ibu dengan skor APGAR bayi baru lahir juga memperlihatkan hubungan sangat bermakna, yang dibuktikan dengan nilai korelasi $r$ $+0,227$ dan keakuratan nilai $\mathrm{p}=0,023$ (nilai $\mathrm{p}<$ $0,05)$ pada menit kelima dan nilai korelasi $r$ $+0,238$ dan keakuratan nilai $p=0,017$ pada menit kesepuluh.

Penelitian ini menunjukkan adanya hubungan korelasi sedang yang bermakna antara kadar hemoglobin ibu hamil pada trimester ketiga dengan berat badan bayi lahir. Data ini bisa bandingkan dengan studi yang dilakukan oleh Telatar B, dkk, terlihat adanya hasil pengukuran berat badan bayi dengan nilai $p=0,036$ dengan korelasi sedang yang dapat diartikan bahwa pada ibu hamil hemoglobin normal dengan ibu hamil hemoglobin rendah memiliki berat badan bayi baru lahir yang berbeda. Hasil penelitian Telatar
B, dkk ini menunjukkan adanya pengaruh anemia pada kasus berat bayi lahir yang rendah. Sebaliknya, pada kasus kadar hemoglobin yang normal, didapatkan berat badan bayi lahir juga normal. 35

Hasil penelitian ini tidak sesuai dengan penelitian yang dilakukan Hassan NE, dkk, yang menunjukkan adanya hubungan negatif antara hemoglobin ibu hamil dan berat badan bayi lahir dengan nilai $p=0,03$ dan korelasi $r=-0,11.32$ Hasil dua penelitian ini kemungkinan berbeda karena adanya pengaruh faktor lainnya seperti nutrisi, gaya hidup dan lain-lainnya. Kedua penelitian ini juga berbeda dari segi etnis negara tempat sampel diambil, dimana penelitian ini sampelnya diambil dari Indonesia, sedangkan penelitian Hassan NE, dkk sampelnya diambil dari Mesir memiliki perbedaan ras dengan indonesia. ${ }^{34}$

Pada penelitian ini didapatkan hubungan korelasi lemah yang bermakna antara kadar hemoglobin ibu hamil pada trimester ketiga dengan panjang badan bayi lahir dengan nilai $\mathrm{p}$ 0,013 dan nilai $r+0,248$. Hasil penelitian ini didapatkan sesuai yang diteliti oleh Telatar yang mendapatkan nilai $\mathrm{p}=0,044$ dan nilai $\mathrm{r}=0,46$ yang berarti adanya hubungan yang bermakna dengan korelasi sedang. ${ }^{35}$

Hasil penelitian ini tidak sesuai dengan penelitian yang dilakukan oleh Hassan NE, dkk, yang juga mendapatkan korelasi negatif yang bermakna antara kadar hemoglobin ibu hamil dengan panjang badan bayi lahir dengan nilai $\mathrm{p}=$ 0,03 dan nilai $r=-0,11 .^{34}$ Hasil olahan sampel ini juga tidak sama dengan penelitian yang dilakukan oleh Laflamme EM. Penelitiannya mendapatkan hubungan yang tidak bermakna dengan korelasi sedang antara kadar hemoglobin ibu hamil dengan panjang badan bayi lahir, karena korelasinya memiliki $\mathrm{p}$ value $>0,05 .{ }^{35}$ Laflamme EM mendapatkan nilai $\mathrm{p}=0,44$ sedangkan penelitian ini mendapakan nilai korelasi dengan $\mathrm{p}$ $=0,013 \cdot{ }^{36}$

Penelitian lain juga dilakukan oleh Yokohama Y, dkk, yang mendapatkan bahwa wanita yang memiliki hemoglobin normal akan memiliki bayi dengan panjang badan $1,5 \mathrm{~cm}$ lebih panjang daripada wanita yang memiliki hemoglobin rendah. ${ }^{37}$ Selain itu, Yokohama Y, dkk juga mendapatkan bahwa panjang badan bayi lahir juga dipengaruhi oleh usia kehamilan dan indeks massa tubuh maternal. Data dari RSUP. M. Djamil Padang menunjukkan hal serupa dimana 
ibu hamil yang memiliki berat di atas $60 \mathrm{~kg}$ memiliki bayi baru lahir dengan antropometri di batas normal indeks tubuh bayi.

Pada penelitian ini didapatkan hubungan korelasi lemah yang bermakna antara kadar hemoglobin ibu hamil trimester ketiga dengan lingkar kepala bayi lahir. Hasil ini didukung oleh studi Telatar, dkk, dengan nilai $\mathrm{p}=0,013$ dengan nilai $r=0,52$ yang berarti memiliki hubungan yang bermakna dengan korelasi sedang yang dapat menunjukkan bahwa lingkar kepala bayi lahir dipengaruhi secara negatif oleh anemia maternal dan berarti anemia berat memiliki hubungan yang signifikan terhadap lingkar kepala bayi yang kecil. ${ }^{35}$ Adanya perbedaan jumlah sampel dan karakteristik sampel pada penelitian ini menyebabkan hasil penelitian yang bervariasi.

Dilihat pada penelitian lain yang telah dipublikasikan mengenai hubungan hemoglobin ibu dengan lingkar kepala bayi baru lahir, sampai saat ini penulis belum menemukan penelitian lain yang menunjukkan adanya hubungan tidak bermakna diantara variabel tersebut.

Pada penelitian ini didapatkan hubungan korelasi lemah yang bermakna antara kadar hemoglobin ibu hamil trimester ketiga dengan skor APGAR 5' dan 10' bayi lahir dengan nilai $\mathrm{p}$ masing-masing 0,023 dan 0,017 dan nilai $r$ masing-masing 0,227 dan 0,238 . Penelitian ini sedikit mirip dengan Akhter $\mathrm{S}$ dkk yang menyatakan bahwa terdapatnya hubungan korelasi sedang yang bermakna dengan nilai $\mathrm{p}<$ 0,001 dan nilai $r-=0,52$ pada penelitiannya terhadap skor APGAR. ${ }^{38}$

Hasil olahan sampel ini tidak didukung oleh beberapa peneliti, salah satunya oleh Budwiningtijastuti, Surjono A, Hakimi M yang meneliti sampel yang sama yaitu hubungan antara hemoglobin ibu hamil dengan skor APGAR menyatakan bahwa hemoglobin ibu hamil tidak mempergaruhi hasil dari skor APGAR bayi baru lahir dengan nilai $p=0,49$ dan nilai $r=1,37$ untuk hubungan hemoglobin dengan skor APGAR 5' dan nilai $\mathrm{p}=0,28$ dan nila $\mathrm{r}=1,82$ untuk skor APGAR $10^{\prime} .39$

\section{Simpulan}

Berdasarkan hasil dari penelitian yang telah dilakukan, dapat disimpulkan bahwa terdapat hubungan yang bermakna antara hemoglobin ibu hamil trimester 3 dengan semua data dari antropometri anak berupa berat badan, Panjang badan, dan lingkar kepala bayi serta skor APGAR bayi yang baru lahir.

\section{Ucapan Terima Kasih}

Ucapan terima kasih peneliti sampaikan kepada seluruh pihak yang membantu dalam menyelesaikan penelitian ini.

\section{Daftar Pustaka}

1. Cunningham F, Gary, Lenovo KJ, Bloom SL, Hauth JC, Williams, McIntire. editor. Edisi 24. Obstetri william. Jakarta : EGC. 2014.

2. Kemenkes RI. Profil kesehatan Indonesia. Jakarta: Kemenkes RI. 2016.

3. Depkes RI. Riset kesehatan dasar. Jakarta: Badan Penelitian dan pengembangan Kesehatan Kementrian Kesehatan RI. 2013.

4. Maghsoudlou S. Cnattingius S. Sthepansson O. Aarabi M. Semnani S. Montgomery M. Bahmayar S. Maternal hemoglobin concentrations before and during pregnancy and stillbirth risk: a population-based casecontrol study. BMC Pregnancy and Childbirth. 2016; 16: 135.

5. Abeysena C. Jayawardana P. and Seneviratne A. "Maternal hemoglobin level at booking visit and its effect on adverse pregnancy outcome," Australian and New Zealand Journal of Obstetrics and Gynaecology. 2010; vol. 50, no. 5, pp. 423-427.

6. Kemenkes RI. Riset kesehatan dasar; RISKESDAS. Jakarta: Balitbang Kemenkes RI. 2013.

7. Dinas Kesehatan provinsi Sumatera Barat. Laporan kesehatan ibu dan anak dinas kesehatan provinsi Sumatera Barat. 2017.

8. Mousumi G. Ranjan K. Maternal anemia, pregnancy complications, birth outcomes: evidence from North East India. Journal of North East India Studies. 2013; Vol. 3. No. 1. Pp. 74-85.

9. Gaur S. Katarina S. Agarwal R. A study of effects of maternal anemia on anthropometric measurements of newborns. The Pharma Innovation Journal. 2015; (8) : 69-71.

10. Hynes G. Cooper C. Dennison E. Parental determinants of prenatal anthropometry in : Preedy VR. Handbook of anthropometry : physical measures of human form in health and desease. New York : Springer. 2012; p 103343.

11. Chouwdhury S. Rahman M. Monirrudin ABM. Anemia in pregnancy. Medicine Today. 2014. Vol. 26. Number 01. Pages 49-52.

12. Ahmad MO, Kalsoom U. Effect of maternal anaemia on APGAR score of newborn. Journal of Rawalpindi Medical College (JRMC). 2015;19(3):239-242.

13. Prawirohardjo, S. Ilmu kebidanan. Jakarta: PT. Bina Pustaka Sarwono Prawirohardjo. 2009.

14. Halim Pendana, I. Hubungan antara kadar hemoglobin dengan prestasi siswa MI Muhammadiyah program khusus Kecamatan Kartasura Kabupaten Sukoharjo. 2015.

15. Asrinah,dkk. Asuhan kebidanan masa kehamilan. Yogyakarta:Graha Ilmu. 2010.

16. Chandra S, Tripahi SA, Mishra S, Amzarul M, Vaish AK, Krause. Psychological changes in hematological parameters during pregnancy. Indian J Hematol Blood Transfus. 2012sept; 28(3): 144-6.

17. Krause. The American Journal of Clinical Nutrition, Volume 61, Issue 3, 1 March 1995, Pages 514-523. 
18. Kutteh MD, Franklin BS. Antiphospholipid antibodies associated with recurrent pregnancy loss: prospective, multicenter, controlled pilot study comparing treatment with low molecular weight heparin versus unfractionated heparin. Volume 83, Issue 3, March 2005, Pages 684-690.

19. Ikhmawati, Y. Hubungan antara pengetahuan tentang anemia dan kebiasaan makan terhadap kadad hemoglobin pada remaja putri di asrama SMA MTA Surakarta. 2013.

20. Flick AA, Kahn DA. Maternal physiology during pregnancy: introduction. In: DeCherney $\mathrm{AH}$, editor. Current diagnosis and treatment obstetrics and gynecology, $10^{\text {th }}$ edition. USA: The Mc-Graw Hill Companies. 2007.

21. Sherwood L, Human physiology: from cells to system, $7^{\text {th }}$ edition. USA: Cengage Learning. 2010; p. 3937.

22. Hattangadi SM, Wong Piu, Zhang L, Flygare J, Lodish HF. From stem cell to red cell: regulation of erythropoiesis at multiple levels by multiple proteins, RNAs and chromatin modifications. Blood Journal. 2011; 118(24): 6258-68.

23. Theml H, Diem H, Haferlach T. Color atlas of hematology: practical microscopic and clinical diagnosis. Germany: Theime. 2004; p. 30-2.

24. Williams. Maternal seafood consumption in pregnancy and neurodevelopmental outcomes in childhood (ALSPAC study): an observational cohort study. Volume 369, Issue 9561, 17-23 February 2007, Pages 578-585.

25. Greer JP, Foerster J, Lukens JN, editor. Wintrobe's clinical hematology, $11^{\text {th }}$ edition. USA: Lippincott Williams and Wilkins Publisher. 2003.

26. Abdulmulthalib. Kelainan hematologik. Dalam: Saifuddin AB, editor. Ilmu Kebidanan Sarwono Prawirohardjo Edisi Keempat. Jakarta: PT Bina Pustaka Sarwono Prawirohardjo. 2010; p.775-80.

27. Rode L, Nilas L, Wojdemann K, Tabor A. Obesity-related complications in Danish single cephalic term pregnancies. 2005; 105: 537-542.

28. Lone FW, Qureshi RN, Emmanuel F, Kurki T. Matenal anemia and its impact on perinatal outcome in a tertiary care hospital in Pakistan. Eastern Mediterranean Health Journal. 2004; 10(6): 801-7.

29. MacDonald MG, Seshia MM, Mullet MD. Avery's neonatology $6^{\text {th }}$ edition. USA: Lippincott Williams \& Wilkins; 2005.

30. Kidanto HL. Newborn mortality and fresh stillbirth rates in tanzania after helping babies breathe training. Pediatric Official Journal of the American Academy of Pediatric. Volume 131, Issue 2. February 2013. Pages 353-359.

31. Prawirohardjo S. Ilmu kandungan: Jakarta. PT Bina Pustaka Sarwono Prawirohardjo. 2011.

32. Clinical Practice Procedures : Assasement APGAR Score. 2016. Queensland Government : https://ambulance.qld.gov.au/clinical.htm.

33. Sastroasmoro S. Dasar-dasar metodologi penelitian klinis edisi empat. Jakarta: CV Sagung Seto. 2011; p. 88$100,372$.

34. Hassan NE, Shalaan AH, El-Masry SA. Relationship between maternal characteristics and neonatal birth size in Egypt. Eastern Mediterranean Health Journal. 2011; 17(4): 281-9.

35. Talatar B, Comert S, Vitrinel A, Erginoz E, Akin Y. The effect of martenal anemia on anthropometric meansurement of newborns. Saudi Med J. 2009; $30(3) 409-12$.

36. Laflamme EM. Martenal hemoglobin concentranal and pregnancy outcome : a study of the effect of elevation in El Alto, Bolovia. MJM. 2010;13(1): 47-55.

https://doi.org/10.25077/jikesi.v1i3.117
37. Yokohama Y, Sugimoto M, Ooki S. Analysis of factor affecting birthweight, birthlength, and head circumference : study of Japanese triplets. Twin Res Hum Genet. 2005; 8(6): 657-63.

38. S Akhter, M A Momen, M M Rahman, R K Karim. Effect of maternal anemia on fetal outcome. 2010; 19(3):3918.

39. Budwiningtijastuti, Surjono A, Hakimi M. Anemia ibu hamil trimester III dan pengaruhnya terhadap kejadian rendahnya skor APGAR. 2005; 18(1); 77-85. 